\begin{tabular}{|c|c|c|c|c|c|c|c|}
\hline & Berkala Arkeologi & 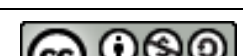 & \multicolumn{5}{|c|}{ Translated Version } \\
\hline & & & ISSN & : & 0216-1419 & E-ISSN & 2548-7132 \\
\hline & Volume 40 No. 2, Nov & DOI: $10.30883 /$ jba.v & & & http & keolo & o.id \\
\hline
\end{tabular}

\title{
APPLICATION OF PHOTOGRAMMETRY TECHNIQUES IN RECONSTRUCTING THE CARVING ON STONE INSCRIPTIONS
}

\author{
PENGGUNAAN TEKNIK FOTOGRAMETRI DALAM \\ REKONSTRUKSI PAHATAN PADA BATU PRASASTI
}

\author{
Goenawan A. Sambodo', Yoyon K. Suprapto², Eko Mulyanto Yuniarno² \\ Electrical Engineering Department, Institut Teknologi Sepuluh Nopember, Surabaya ${ }^{1}$ \\ Electrical Engineering Department and Computer Engineering Department, \\ Institut Teknologi Sepuluh Nopember, Surabaya ${ }^{2}$ \\ sambodo.19071@mhs.its.ac.id
}

\begin{abstract}
ABSTRAK
Penelitian ini membahas dan menguji teknik fotogrametri untuk mengetahui kedalaman pahatan pada batu prasasti sehingga rekonstruksi dapat dilakukan guna memperjelas bekas pahatan aksara yang ada. Diharapkan akan dapat memunculkan gambar pahatan dengan lebih jelas sehingga pada akhirnya pahatan tersebut dapat dibaca. Prasasti adalah tulang punggung penulisan sejarah kuna Indonesia. Arti penting prasasti ini belum dapat digunakan dengan maksimal karena banyak prasasti yang ditemukan dalam keadaan aus pahatannya, baik karena kerusakan yang disebabkan oleh faktor alam maupun manusia. Teknik Fotogrametri belum banyak digunakan oleh peneliti dari Indonesia untuk membantu menganalisis benda cagar budaya yang ada terutama prasasti. Selain mengulas beberapa teknik fotogrametri dikemukan pula percobaan teknik fotogrametri yang telah dilakukan khususnya yang berhubungan langsung dengan prasasti. Rekonstruksi yang dilakukan tidak dimaksudkan untuk membaca dan mengartikan hasil pembacaan aksara prasasti, akan tetapi lebih kepada memberi pandangan baru dan potensi penggunaan teknik fotogrametri bagi para ahli epigrafi tentang cara lain dalam memperjelas bekas pahatan yang telah aus.
\end{abstract}

Kata Kunci: Rekonstruksi; prasasti; fotogrametri; dokumentasi

\section{ABSTRACT}

This research discusses and applies photogrammetry techniques to determine the depth of the script carvings on some worn-out stone inscriptions so images of scripts can be more readable. Inscriptions are the backbone of ancient Indonesian historical writings. Unfortunately the significance of many such ancient inscriptions can not yet be used optimally since many inscriptions are found in a state of having poor legibility, and this due both to natural as well as human factors. To this day, photogrammetry techniques have not been widely used by Indonesian researchers in order to help analyze existing cultural heritage objects, especially stone inscriptions. In addition to previous photogrammetric techniques reviews, this article also brings forward my experiment on the photogrammetric techniques, especially those directly related to the stone inscriptions. The reconstruction was not intended to interpret the meaning of the scripts, but rather to give epigraphists a new insight into other ways of clarifying worn-out scripts.

Keywords: Reconstruction; inscription; photogrammetry; documentation

$\begin{array}{ll}\text { Article Submitted } & : 23-06-2020 \\ \text { Article Accepted } & : 27-08-2020\end{array}$ 


\section{INTRODUCTION}

Many studies regarding inscriptions are stating that the researchers could not done better because the carved characters were missing, worn or faded (the manuscript made of cloth or paper). Writing, either on hard objects such as stones and metal or soft objects such as leaves and paper, is very important in a culture. J.G. de Casparis states that in the archipelago, writing had been used for nearly sixteen centuries, and if the writing could be well documented and reconstructed, then all of that would be an important added value in compiling the history of civilization in which the writing was found (Casparis , 1975, p.1). Inscriptions are cultural objects that contain written numbers or ancient characters. Although the actual meaning of prasasti (Indonesian for inscription) in Sanskrit is "praise", in its development the word is considered as "a charter, edict, decree, law, or writing".

Among scientists in their fields, inscriptions are also referred to as "inscriptions", while ordinary people refer to them as "watu tulis" (written stones) or "stones with letters". The definition of inscription refers to historical sources written on stone, metal, wood and horns, and all hard materials, most of which were made by order of the ruler of an area. The mention of the inscription in this paper will always refer to that definition. In a general sense, inscriptions can be interpreted as relics of the past in the form of writing inscribed on the surface of rough objects, especially stone and metal as the medium. The incision on the hard media uses a chisel, most likely made of iron. There is no evidence of this carving/ engraving tool yet, but from comparisons made to stone carvers in Trowulan or Muntilan, as well as metal carvers in Kotagede, Yogyakarta, it is known that they use metal chisels that are adjusted to the size of the media and the size of the letters to be written.

Boechari $(1977$, p. 4) states that the task of epigraphers today is not only to examine unpublished inscriptions, but also to re-examine the published transcriptions of inscriptions. Still according to Boechari, in carrying out this task the epigraphers encountered many difficulties, including in stone-media inscriptions. The high level of stone wear and tear makes the stone carvings very difficult to read. The readings must be done repeatedly to get satisfactory results.

The damage that occurred could be due to two main reasons. First, damage caused by natural factors such as volcanic eruptions, floods, earthquakes and weather. These natural occurrences often cause inscriptions to be lost, break or become worn. An example of this is the inscriptions around Sendang Legi, Lamongan. The inscription, which made of stone with large pores, are damaged due to the absence of protective structures that cover the stones and also the presence of biological deterioration agent such as fungi, algae or moss. The presence of mold, algae or moss on the inscription stone which is rarely cleaned over time will deteriorate the inscription.

The second damage is caused by human activity, whether done intentionally, such as because of a war, or intentionally deleted some lines on the inscription, or even destroying it because it is considered not in accordance with their custom at their times. Another intentional damage is usually caused by looters, when they find a stone inscription which is too large to carry, they will break the stone into several pieces. They usually also only take the parts that have inscriptions and leave the uninscribed parts behind. Another example of damage 
is the covering of the carving. These kinds of damage are usually caused by a layer of paint or etc. that was meant to clarify the inscription, or even to protect it from weathering. Incorrect handling of stone inscriptions is more than a possibility which cause damages.

Physical damage to stone inscriptions is generally caused by weather and the original carving is thin. Over time the carvings become thinner, and eventually will leave only scars. This is exacerbated by the fact that most of the stone inscriptions that are still in their original location (in-situ) are not provided with roof protection, hot and rainy weather exacerbates this damage. Although the scars can still be seen by the eye, they are very difficult to read properly. An example of the broken stone inscription can be seen in Figure 1.

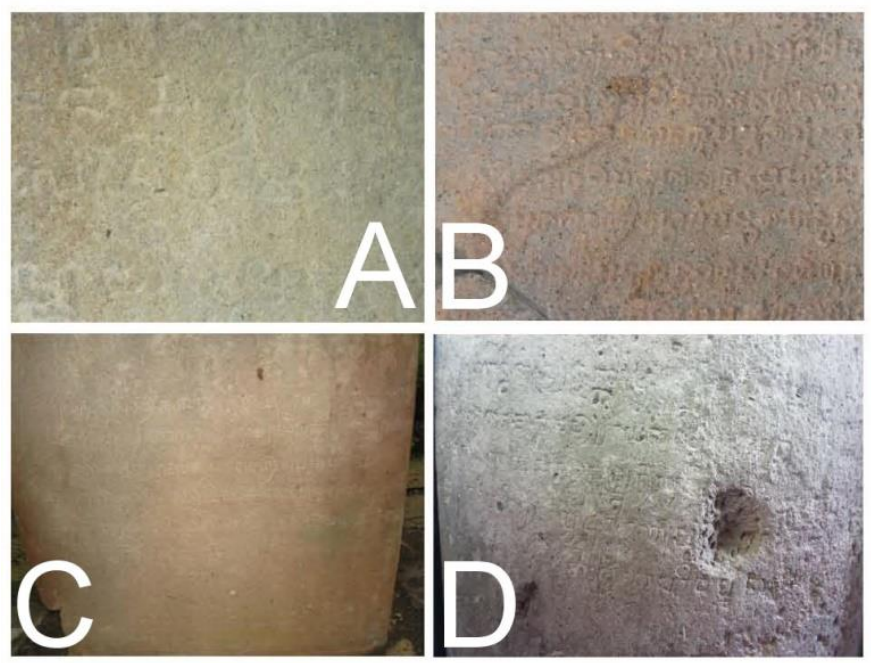

Figure 1. Damages on Stone Inscriptions

A. Sculpture damage due to the thinning depth of the sculpture. B. Damage to the sculpture which, although still visible, is difficult to read directly due to the wide angle of the sculpture. C. Damage to the sculptures due to the unequal thinness of the sculptures. D. Damage to sculptures due to sculpting that is worn due to weather and time and broken rock parts (Source: Goenawan A. Sambodo)

In the past, the documentation of inscriptions used very simple methods. Making negative prints from paper (absklat), making positive prints from paper (rubbing) or writing directly the shapes of letters/characters on the stone (facsimile). The results obtained by documenting in this way were depending on the expertise of the person doing the recording. In addition, recording or documenting inscriptions in the ways mentioned earlier was very time consuming when carried out in the field. Documentation results were not standardized and take a long time to get the expected results. There are also weaknesses for those methods, but although through year of practices those weaknesses are already known, there has not been much effort to overcome them. Figure 2 are showing how these methods undergo and their results. 

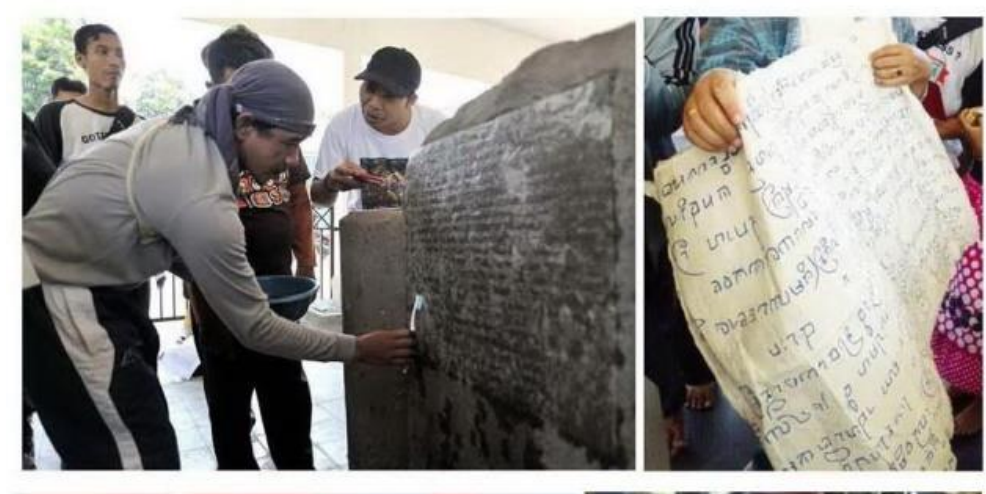

A
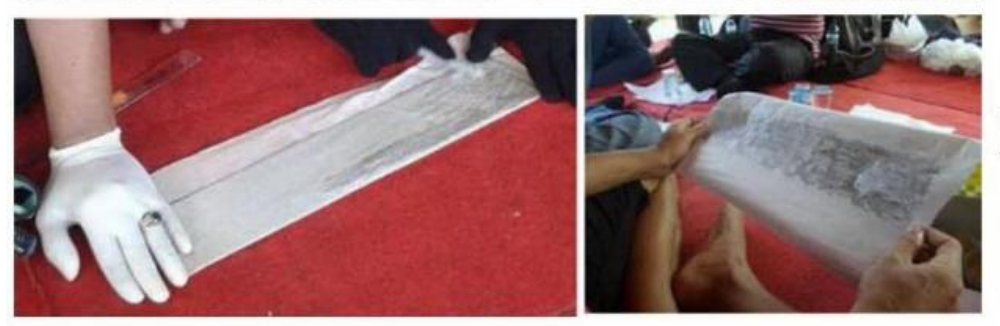

B
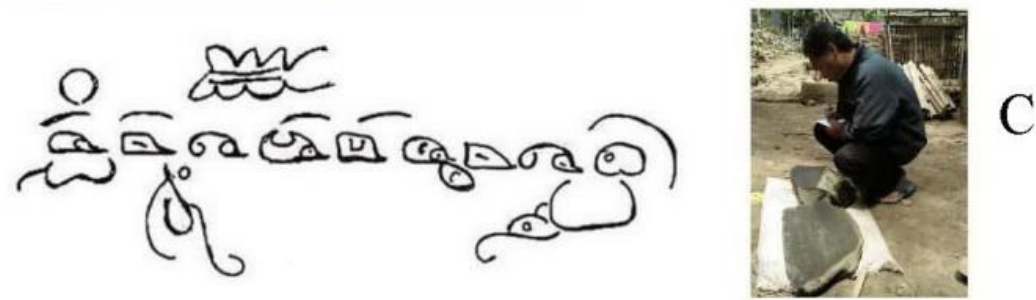

Gambar 2. Techniques in Inscription Documentation and Their Results

A. absklat technique; B. rubbing technique; C. facsimile technique

(Source: A, B and C (right) Goenawan A Sambodo, C (left) Berkala Arkeologi vol. 14, 1994, p. 8)

There is one other way to document manuscripts or inscriptions with a more advanced method, namely by means of photographs. Through photos, documenting an object of cultural heritage, especially an inscription, can be faster and more accurate. However, this method requires additional equipment which is still quite expensive and cannot be used by many people in the past. In its current development, photo equipment and technology have become increasingly easy to obtain at affordable prices and their use is increasingly widespread in society. Documenting cultural objects, especially inscriptions, is no longer a necessity for related government agencies, but has spread to all levels of society.

However, not much has been done through digital techniques to further clarify the letters carved on inscriptions - especially those that are thinly or worn to make them easier to read. Some of the efforts that have been done are using a common image processing application such as Photoshop. However, this application still has several shortcomings, one of which is the addition of lines to clarify the appearance of the processed inscriptions. When drawing lines for unclear characters, these lines can be regarded as very subjective and depending on the person doing the processing. One different or incorrect line can give us different characters. An example of the results of use that has been done is as shown in Figure 3. 

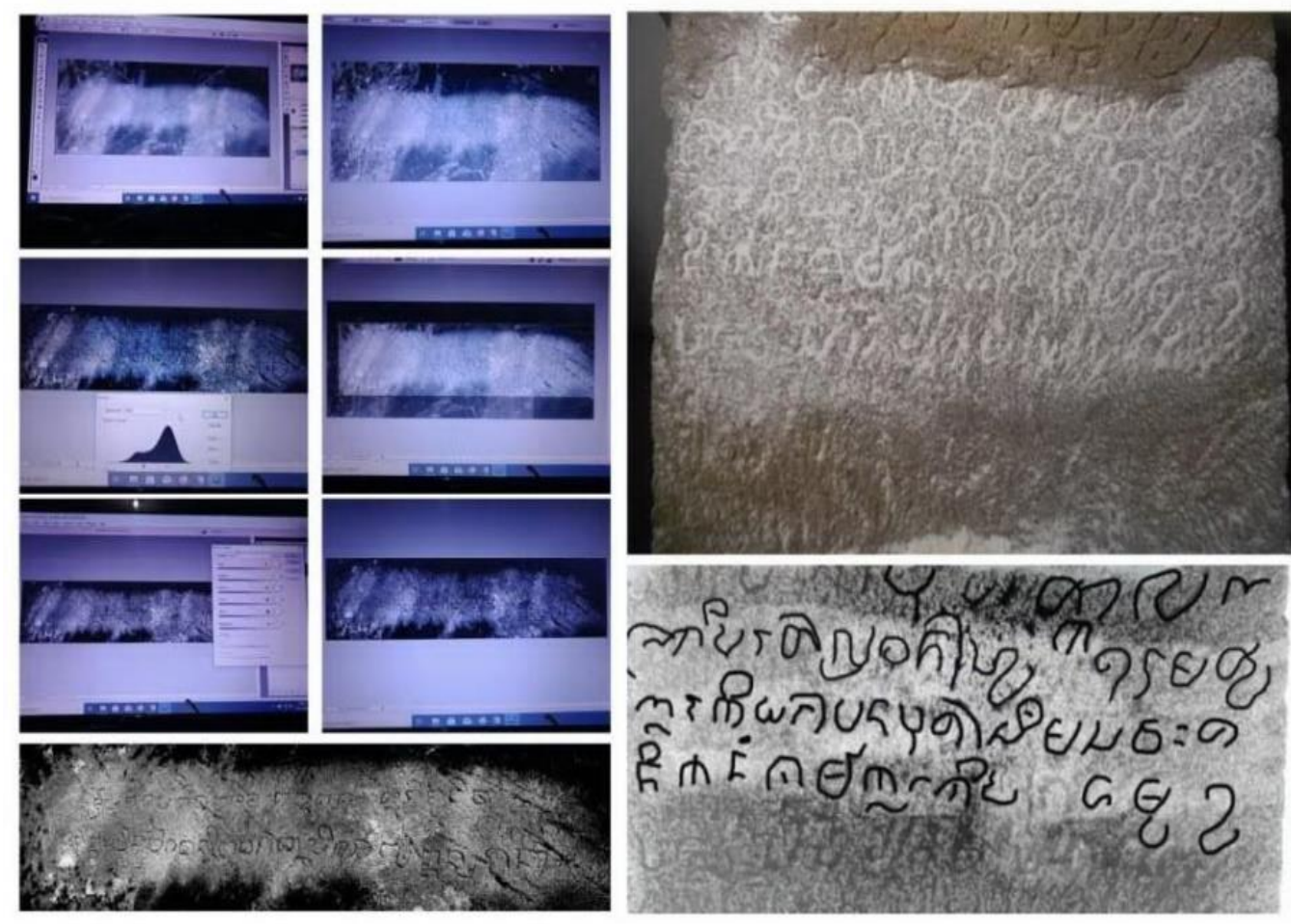

Figure 3. The Processing Results Using Photoshop Image Processing Application

(Source: Goenawan A. Sambodo)

Based on those issues regarding inscription, this paper will discuss the efforts that have been made by many researchers and writers to detect threedimensional stone inscriptions using photogrammetric techniques. The photogrammetric method generally uses a minimum of two images of the same static scene or object obtained from different viewpoints. Similar to human vision, if an object is visible in at least two images (which is called parallax) it allows stereoscopic views and the derivation of 3D information from the view that is visible in an overlapping area of the image. This method was chosen because until now, the use of computational technology assistance in the field of archaeology, especially epigraphy (reading ancient characters) in Indonesia, is still lacking. Most of the existing computational technology aids are directed at reconstructing buildings, artifacts or relief sculptures in the temples.

This paper is attempting to introduce the use of photogrammetric technology in archaeological research in general, more specifically in epigraphy research. The objectives of this paper are (1) Introducing the ways that can be done with photogrammetric techniques to detect carvings and reconstruct them in wellmeasured ways and minimize physical treatment of the inscription (non-invasive); and (2) From this introduction, it is hoped that more researchers will use this method and decreasing the numbers of unreadable inscriptions.

By measuring and minimizing physical (non-invasive) treatment of the stone carvings, especially on inscriptions, it will produce a better possibility of inscription legibility. In the long term, it is hoped that the documentation of weathered carvings on stone inscriptions can be done digitally in 3-dimensional form with optimal accuracy. This will lead us to a refinement of photogrammetry 
method and making digital restoration and 3-dimensional duplication possible for research and exhibition purposes.

Image matching techniques that are part of image processing are a very important technological advancement in the realm of photogrammetry and computer vision. This technique allows us to build dense point cloud (pointcloud) which is derived from a $2 \mathrm{D}$ image. In the context of cultural heritage documentation, this technique opens opportunities for 3D documentation and reproduction of cultural heritage objects which are found incomplete/ partially, or in the form of unreadable carving on inscriptions. In some places and perhaps even in some archaeological research it is still not widely used. The most common use of data is in 2D (through drawings, sketches, and photographs).

\section{METHODS}

As stated by Gajski et al. (2016, p. 263):

"Many valuable artifacts are small (a few centimeters or less). Relevant documentation of such artifacts is mainly limited to subjective interpretations and manual drawing techniques using a magnifying glass. Digital photogrammetric techniques allow high accuracy measurements and such techniques can be used to produce relevant archaeometric documentation with a high level of detail".

This is the basis of the use of photogrammetric techniques, especially close-range or macro-photogrammetry, in the reconstruction of carving on stone inscriptions. The basis of this photogrammetric method is an attempt to change the twodimensional shape of a flat plane to a three-dimensional shape so that geometric measurements of length and height can be made.

Nicolae et al. (2014) proposed that the stone surface was seen as the surface of the earth and the parts of the carve as a small scale of a valley bounded by slopes and peaks. One of the easiest tools commonly used to analyze hill shadows is to simulate light in a DEM surface model. This method is a better adjustment in order to clarify the existing carving relief forms. The method proposed by Nicole has previously been used by Jasiewicz and Stepinski (2013) and Victor Klinkenberg (2014) with different research data. Jasiewicz used aerial photo data from the plains in Poland. The method used was later adopted by Monna (2018) in his research on menhir relief in Mongolia. Below we will be briefly explained regarding what Jasiewicz (2013) calls the local ternary pattern and geomorphones which have also been discussed by Yokoyama et al. (2002).

Geomorphons are terrain attributes and landform types, one DEM scan produces a geomorphic map. Determination of the local pattern is done by using the surrounding environment, with size and shape that adapt to the local topography. The Local Ternary Pattern (LTP) is a further application of the local binary pattern (LBP) which is a method of extracting certain features that are characteristic of an image. Grayscale images and the DEM are the same because both are single-valued rasters. Jasiewicz (2013, p. 148) states that in the field of computer vision, it has long been recognized that an image should be segmented 
into its constituent structure based on similarity in texture. Local Binary Patterns (LBP) are introduced as texture descriptors. LBP is built from the local $3 \times 3$ environment on top of the central cell; The 8 neighbors are labeled 0 , if the neighbor's gray level is less than the central cell's gray level, or 1 otherwise. Local Ternary Patterns (LTP) extend LBP to a 3-value pattern leaving a small level of contrast perceived as a lack of contrast. Thus, neighbors are labeled 1 if their value exceeds the value of the central cell by at least $t$, where $t$ is the specified threshold value. The neighbor is labelled 1 if its value is at least $t$ and less than the value of the central cell. Otherwise, the neighbor is labeled 0 . The original LBP is too simple to be a value for DEM analysis, where higher, lower or level concepts/ ideas are still important, but the LTP, while still simple, provides sufficient structure to be used for identification of the main elements of DEM landform.
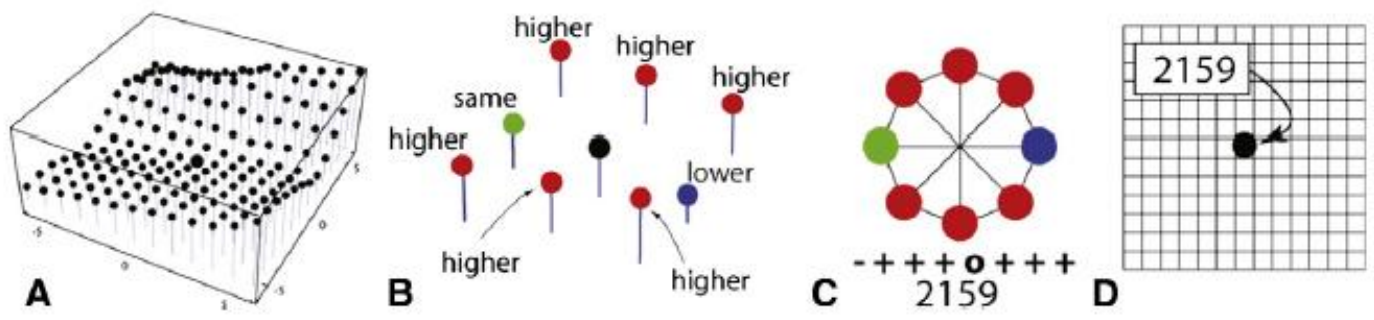

Figure 4. The Usage of the Concept of Local Ternary Pattern (LTP) in the Classification of Earth Surface Elements.

(A) DEM around tested section; (B) Ternary representation which is the relative elevation between the tested section and the surrounding areas; (C) Three different forms of ternary pattern; (D) Assignment of LTP to cells in rasters

(Source : Jasiewicz and Stepinski, 2013, p. 149)

Figure 4 illustrates the concept of applying LTP for landform classification. Panel A shows a portion of the DEM in the central cell environment. From visual observation, it is clear that the central cell has a landscape element in the form of a valley. Panel B only shows the 8 direct "neighbors" of the center cell - which are labeled with different colors to indicate whether the altitude value is higher, lower, or has the same height value as the center cell. Panel $C$ shows the ternary pattern derived from the label "neighbor". This pattern can be represented in three different ways.

First, visually as an octagon with each dot colored according to the convention used in Panel B. Second, as a string of three symbols (+ = "higher", - = "lower", and $0=$ "equal"); The first symbol in the string corresponds to the eastern neighbor and the next symbol corresponds to the neighbor in counterclockwise order. Note that patterns in the form of strings can also be regarded of as ternary numbers (numbers represented in base 3 ) which can be converted to decimal numbers. Thus, the final representation of the pattern is the corresponding to decimal number (2159 for the pattern shown in Fig. 2.2). This concise representation serves as a pattern label, but it is important to emphasize that the entire pattern structure can be recovered from the label. Finally, panel D shows that the central cell has been classified as geomorphon \# 2159.

In practice, the ternary pattern characterizing the terrain type in the center cell environment is determined not from a simple elevation difference (as 
illustrated in Figure 2.2 for conceptual purposes), but rather of the quantity $\Delta$ obtained by local characterization of the surface using the "line-of-sight principle". This principle was originally proposed by Yokoyama et al. (2002) with respect to the notion of terrain openness, relating surface relief and horizontal distances in a manner called zenith and nadir angles along the eight major compass directions. To compute the zenith and nadir angles in the center cell, eight height profiles starting from the center cell and extending along the main direction up to the "search distance" $\mathbf{L}$ where extracted from the DEM. The elevation angle is the angle between the horizontal line and the line connecting the center cell with the points located on the profile. The elevation angle is negative if the point on the profile has a lower height than the center cell. For each profile, a set of DSL elevation angles is calculated; symbols indicating this set indicate dependence on direction (D) and search distance or scale $(\mathbf{L})$. Profile apex angle is defined as ${ }_{\mathrm{D}} \boldsymbol{\Phi}_{\mathrm{L}}=\mathbf{9 0}{ }^{\circ}{ }_{\mathrm{D}} \boldsymbol{\beta}_{\mathrm{L}}$, where ${ }_{\mathrm{D}} \boldsymbol{\beta}_{\mathrm{L}}$ is the maximum elevation angle in ${ }_{\mathrm{D}} \mathrm{S}_{\mathrm{L}}$ Similarly, the profile nadir angle is defined as ${ }_{\mathrm{D}} \boldsymbol{\Psi}_{\mathrm{L}}=\mathbf{9 0 ^ { \circ }}{ }_{-}{ }_{\mathrm{D}} \boldsymbol{\delta}_{\mathrm{L}}$, where ${ }_{\mathrm{D}} \boldsymbol{\delta}_{\mathrm{L}}$ is the minimum elevation angle in ${ }_{\mathrm{D}} \mathrm{SL}$.

Thus, the zenith angle is the angle between the zenith and the line of sight, and the nadir angle is the angle between the nadir and the hypothetical line of sight resulting from the reflection of the elevation profile with respect to the horizontal plane. Both zenith and nadir angles are positively defined and range from $0^{0}$ to $180^{\circ}$. The slot value in the ternary pattern corresponding to the direction $\mathbf{D}$ and the search distance $\mathbf{L}$ is denoted by the symbol ${ }_{D} \boldsymbol{\Delta}_{\mathbf{L}}$ and is given by equation (1) taken from Jarosław Jasiewicz and Tomasz F. Stepinski (2013):

$$
{ }_{D} \Delta_{L}=\left\{\begin{array}{cl}
1 & \text { if }{ }_{D} \psi_{L}-{ }_{D} \phi_{L}>t \\
0 & \text { if }\left|D_{\psi L}-{ }_{D} \phi_{L}\right|<t \\
-1 & \text { if }{ }_{D} \psi_{L}-{ }_{D} \phi_{L} \mathrm{~b}-t
\end{array}\right.
$$

There are two independent parameters in the formula. above, one is the search distance $\mathbf{L}$ and the other is the flatness threshold $t$. The advantages of using a line-of-sight environment rather than a grid-based environment in calculating ternary patterns become clear by observing that, choosing value $\mathbf{L}$ a much larger will result in the identification of landform elements regardless of scale. In practice, using larger values of $\mathbf{L}$, we can simultaneously identify landform elements over a wider range of scales than is possible in a grid-based environment.

Figure 5 illustrates the concepts of zenith and nadir angles and explains the need to use both in the definition of $\Delta$. This figure shows a hypothetical elevation profile across the west-east line. Both places are selected and marked by A and B respectively. Visually they can be characterized as peaks and pits (or ridges and valleys, if we imagine the same height profile extending in the third dimension). 


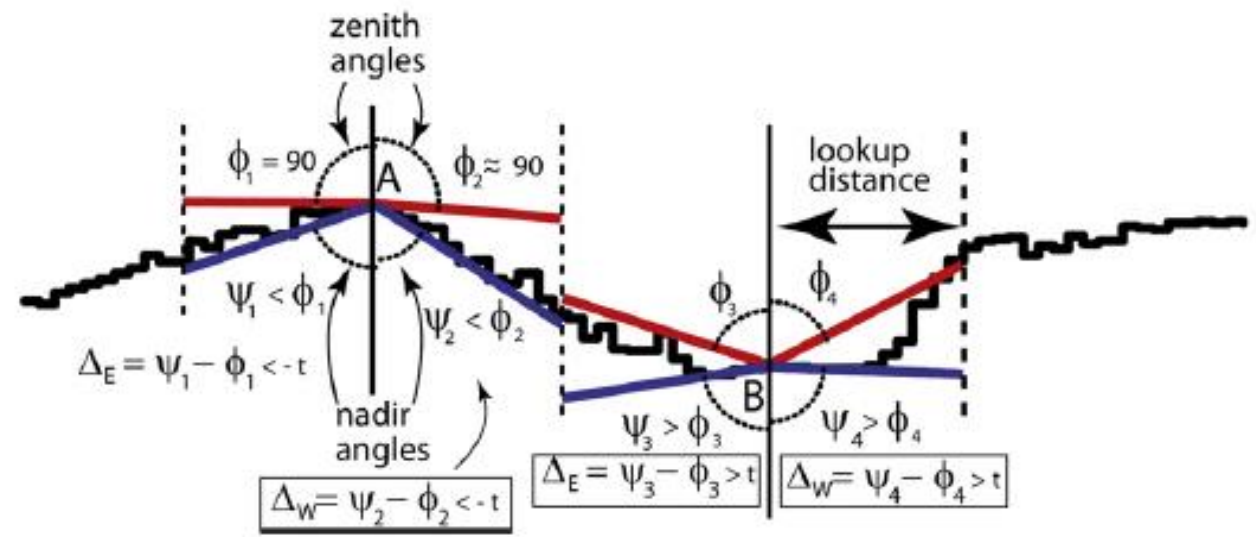

Figure 5. Depiction of the Concept of Zenith and Nadir Angles and Their Relationship to the Number $\Delta$.

(Source : Jasiewicz and Stepinski, 2013, p. 149)

Each point of profile increases interest in two main directions (west and east) and adjusted for zenith and nadir angles. The $\Delta \mathrm{s}$ value at point $\mathrm{A}$ is both negative, indicating a peak or ridge, while the $\Delta s$ value at point $B$ is both positive, indicating a pit or valley. If you only use the zenith angle to determine $\Delta$, the absolute value of $\Delta \mathrm{s}$ at point $\mathrm{A}$ will be very small - below the flatness threshold indicating a flat terrain. This is because, in this particular terrain configuration, the line-of-sight of the ground at point $\mathrm{A}$ is determined by the immediate environment. The use of zenith and nadir angles will eliminate such a problem.

Geomorphones are a set of ideal and complete landform elements. All DEM cells were scanned and in each cell ${ }_{\mathrm{D}} \boldsymbol{\Delta}_{\mathrm{L}}$ values were calculated for all eight main directions. These values are entered into the above equation to get a ternary pattern and the decimal labels of the pattern are stored in cells according to their location. The resulting classification of landform elements and their corresponding maps is useful for research on specific types of landforms in the selected area. However, for general purposes the number of landform elements in the geomorphometric map needs to be reduced. This is achieved by grouping the geomorphones into classes corresponding to the most familiar landform elements, as illustrated in Figure 6.

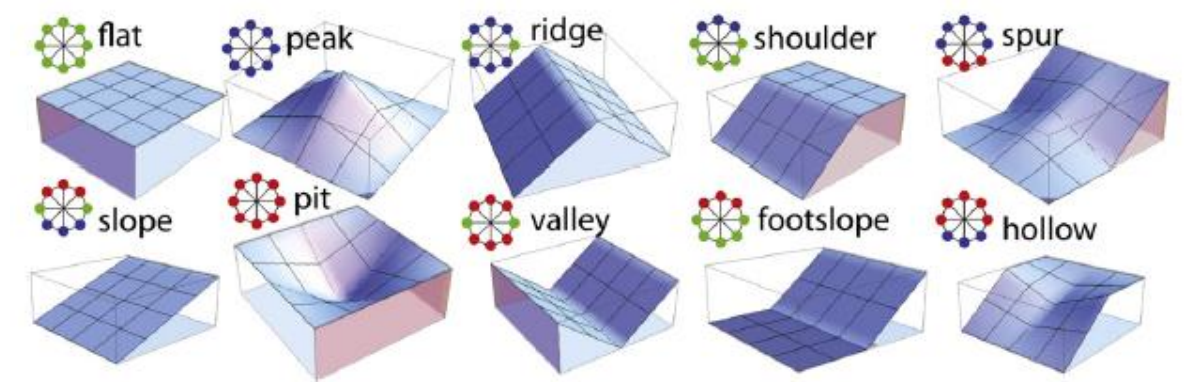

Figure 6. 3D Symbols From Morphology and Their Relation to Geomorphic Forms for 10 Common Elements on Earth's Surface

(Source : Jasiewicz and Stepinski, 2013, p. 150) 


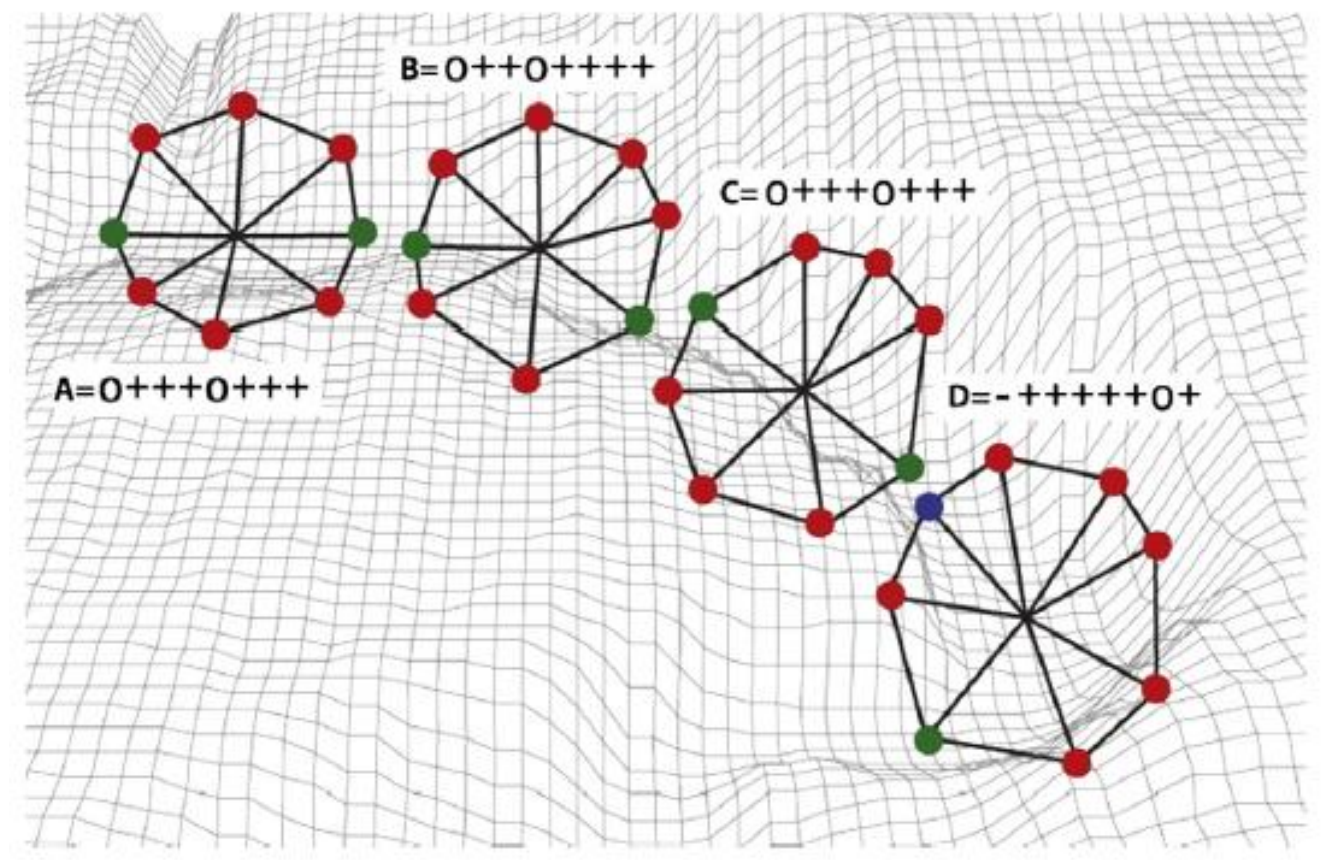

Figure 7. Illustration of Various Geomorphic Surfaces Connected by Semantic Elements to Form a Aingle Surface A, B, C and D Calculated From Different Points Along the Valley Indentation.

(Source: Jasiewicz and Stepinski , 2013, p. 151)

Figure 7 explains that there is a surface that is dominated by valleys. Geomorphones have been counted at four different locations (denoted by the letters A, B, C, and D, respectively) located along this curved valley. The geomorphones at locations $\mathbf{A}$ and $\mathbf{C}$ have a ternary pattern that is identical to the basic "valley" pattern as shown in the Geomorphon at location B which has a slightly different ternary pattern but with the same number $(-1)$ and (1) ternary elements as the geomorphones at location $\mathbf{A}$ and $\mathbf{C}$. A geomorphon at location $\mathbf{D}$ has not only a slightly different pattern but also a slightly different number of ternary elements (it has one $(-1)$ element). Thus, there is more than one morphology of archetypal regions which semantically corresponds to a "valley." Therefore, the procedure for obtaining a geomorphometric map showing the 10 most common landform types is to scan a raster containing the pre-calculated geomorphic labels and replace the label in each cell with one of the 10 landform types using the lookup table. The table has been made by Jasiewicz (2013: 150) as a complement to his presentation.

\section{RESEARCH RESULTS}

Murtiyoso and Suwardhi (2017, p. 255) state that, easier documentation with photogrammetric techniques will open opportunities for conservators, surveyors, or archaeologists to do it using relatively low-cost devices. The minimal equipment needed is a camera, computer, and measuring device to give the object a scale factor. This is a major breakthrough in the realm of 3D documentation, as an alternative (or complement) to laser scanning techniques. On the other hand, 
some open source software can also produce very good results comparable to high-end commercial software.

According to Grün et al. (2004, p. 197) the advantages of photogrammetry and image-based approaches are that:

(i) image contains all the information necessary for 3D reconstruction, accurate and realistic documentation (geometry and texture);

(ii) photogrammetric instruments (cameras and software) are generally inexpensive, highly portable, easy to use and with very high potential for accuracy;

(iii) objects can be reconstructed using archived images even if they have been lost or changed.

Several researchers from abroad such as Nicolae et al. (2014), Papadaki et al. (2015), Monna et al. (2018), Sapirstein (2019) is known to have carried out research on stone carvings, both in the form of reliefs (two or three-dimensional sculptures) and inscriptions, with the help of photogrammetric techniques. This shows that the use of photogrammetric techniques is very helpful for research on stone inscriptions. Even the research results of Sapirstein et al. (2019) managed to solve the problem of a long debate for 150 years with the help of this photogrammetric technique.

Monna et al. (2018) conducted a research on the carvings of menhir stones in Mongolia known as "Deer Stones" with several stages, namely taking photos and continuing with computational work in the laboratory which resulted in evidence that the use of photogrammetry to clarify the carvings on stones would be very helpful to reveal the original form. The computation method used is a photogrammetric data retrieval using the approach Structure from Motion (SfM) rendered as a 3D shape in Mesh, added a Digital Elevation Model (DEM) and Orthomosaics so that the result of the reconstruction will be clear. However, the data chosen by Monna were sculpted menhirs which according to her were still clear enough to be recorded. He did not take samples from less clearly carved or worn stones as research data (Monna et al., 2018).

One thing that is not suitable when applied to field conditions in Indonesia and Java in particular, more specifically in the case of existing inscribed stone is the difference in the shape of the carvings between reliefs and characters. In some cases, carvings relief have clear patterns or rules, for example the character A, because it depicts a god, the size is head $x \mathrm{~cm}$, hand $\mathrm{y} \mathrm{cm}$ and so on as in the Manarasilpasastra book. In contrast to letter carvings which are highly dependent on the hand movements of each sculptor which cannot be standardized. For example, especially in Java, the handwriting of a person and another will have a certain different style even though they write the same word.

Sapirstein (2019) tries to more broadly examine the sculptures on inscribed stones in the temple of Apollo in Sicilly, Italy, which is a relic of the Greek era. With the lighting technique from various angles producing different images when viewed with the help of computational technology, the image of the engraving can be read more clearly compared to previous readings. The computational results obtained are a combination of 2.5D and 3D. A long debate for 150 years was resolved by the results of this study. It revelas that rendering (the process of 
digitally arranging the pixels to compose an image into a new image) of digitally enhanced data is an important new tool and means for textual autopsy, which in the past relied heavily on the authority of researchers that created the transcriptions. In a more objective way, the data recording and the visual presentation of the original carved surface can lead to a more reliable reading for corrupted ancient texts. The data chosen by Sapirstein are sculptures made of marble, which has a high level of density.

In Java, very few stone inscriptions made of marble have been found. Most of the stone inscriptions found use andesite stones with different levels of porosity, in northern Java there are many inscriptions made of limestone. Andesite, which has a relatively high porosity, when the worn carving makes it very difficult to read, moreover with limestone which basically has a higher level of porosity. This resulted in some limestone inscriptions leaving only their physical form as stone inscriptions without ever knowing the engraving/ carving in them because a smooth surface is what they left.

Nicolae et al. (2014) said that the process of creating accurate and reliable 3D textured models from 2D images has become a major endeavor in the field of cultural heritage. Furthermore, he said that photogrammetry can be a valid and reliable technique for making 3D models of museum artifacts. Its main objective is to build some core specifications for data acquisition and modeling, to ensure the scientific quality of the data and the interoperability of the 3D model with archaeologists and conservators. The proposed methodology aims to test and to take advantage of some of the algorithms used in remote-sensing. Especially in the section using high-resolution topographic data (such as LiDAR) to find out, from the DEM (Digital Elevation Model) the special appearance of a surface, such as valleys, ridges, peaks, holes or other changes associated with archaeological sites. In this study, the stone surface is seen as the surface of the earth and part of the carving as a small scale of the valley bordered by slopes and peaks. One of the easiest tools commonly used to analyze hill shadows is to simulate light in a DEM surface model. This is the same method used in the old photographic technique of exposing a surface with the help of light coming from a certain side of the object. Although the depth of the holes cannot be identified by the use of this light, multiple virtual light sources can be calculated to mitigate this problem.

The data used as examples for this study are objects that have been in 3dimensional form since the beginning, namely statues made of stone, bronze and ceramics. Papadaki et al. (2015) said in their paper that there are two alternative, non-invasive, non-destructive techniques to replace traditional and invasive techniques, which aim to help epigraphers to reveal and analyze weatherdamaged characters from ancient Greek inscriptions carved into stone or marble.The recommended technique is based on making a 3D model of the inscription engraved surface through Structured Light Scanner Data followed by the Structure from Motion procedure. The results show that the 3D Model is able to reveal the defective letters, even though the procedure is time-consuming, laborintensive and costly. The results of processing and analysis are checked and evaluated by a specialist in terms of detail, accuracy and quality of the model, as well as the ability to reveal defective or "hidden" letters and finally decipher the inscription. The specialist referred to in this case is an epigraph who understands 
and masters the old letters in the object under study. It is necessary to select the right sample data so that the expected objectives are as expected as well. Research using photogrammetric techniques will build a hypothesis that we will be able to reconstruct the existing inscription on an inscribed stone. It is hoped that with this, the problems that have been in the field so far, namely the difficult reading of the stone inscriptions which are constrained due to the high wear and tear of the stone will be resolved properly.

\section{DISCUSSIONS}

Some of the photogrammetric methods the author has used on stone inscriptions are Reflectance Transformation Image (RTI) and Close-Range Photogrammetry. RTI is a method of retrieving data through the light reflection, processing it to produce a reconstruction of the data that has been taken. In short, it can be said that taking $2.5 \mathrm{D}$ data is processing it into $3 \mathrm{D}$ data and reconstructing it.

RTI images are made from information derived from several digital photos of the object taken from a stationary camera position. In each photo, light is projected from a different direction. This process produces a series of images of the same object with different angles of lighting and shadows. Each RTI resembles a single, two-dimensional (2D) photo image. Unlike a typical photo, the reflected information comes from the three-dimensional (3D) form of the image subject and is encoded in per-pixel images, so that the synthesized RTI image "knows" how light will reflect off the subject. When RTI is opened in the RTI display software, each constituent pixel can reflect the software's interactive "virtual" light from any position the user chooses. The interplay between light and shadow in this image reveals the fine details of the object's 3D surface. The explanation above can be seen in Figure 8.

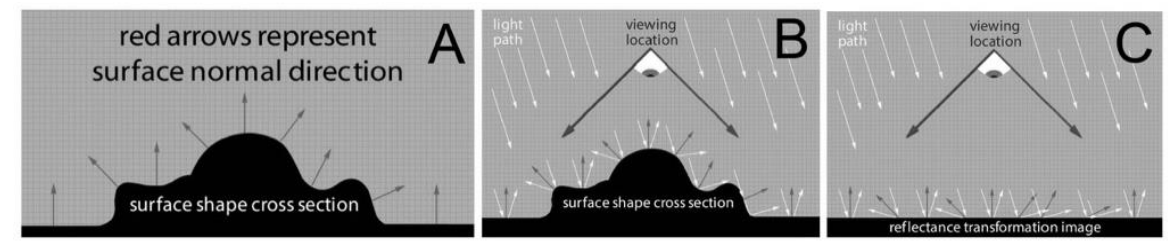

Figure 8. The Process of Light Reflection in a Reflectance Transformation Image A. The direction of a normal surface is a vector that is mathematically perpendicular to the surface at a given location. Technically, the vector is perpendicular to the plane of the tangent at any point on the surface because the surface is real in $3 D$, while the graph shown is $2 D$

B. The light that bounces off the surface is such that the angle of incidence of light and angle of reflection of light is the same angle as normal surface. Because the camera is in a fixed position, and the light origin of each image is known which is an example of various light positions, the RTI software can calculate the normal surface of each pixel in the image.

C. Shows reflection information captured in the RTI. Normal mathematical descriptions are stored per pixel, along with RGB (Red-Green-Blue) color information from ordinary photos. The ability to efficiently record colors and information in true 3D is the strength of documentation with RTI

(Source: http://cultureheritage.org/Technologies/RTI ) 


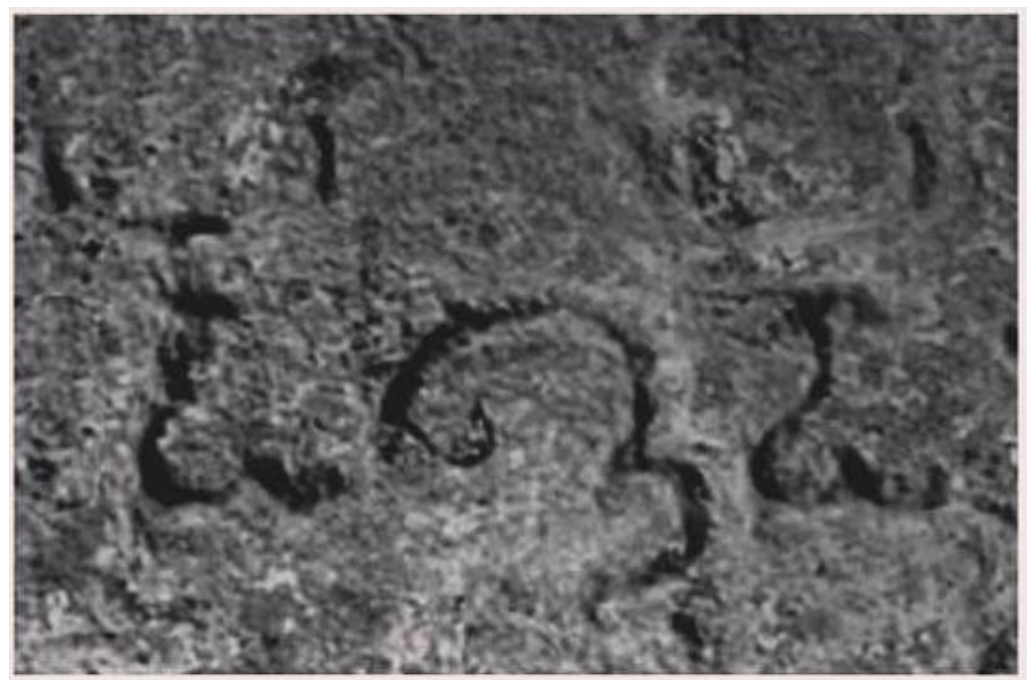

Figure 9. RTI Usage Results on Pucangan Inscription Line 6, Showing Number 929 as the Year Number

(Source: Goenawan A. Sambodo documentation)

This method is still recognized as the best way to obtain images from cultural heritage objects that are worn or damaged, however, it requires a large amount of money to do so because a lot of equipment is used and also takes a long time compared to taking photos through ordinary cameras. The results of the RTI technique that the author has done can be seen in Figure 9. The image is produced using several photos of the Pucangan Inscription taken from various different lighting angles. The results of image processing show clearer engraved characters as shown in the engraving of the Pucangan inscription image line 6 in Figure 9. The photo processing result clearly reads the number of the year "929". The reading of the number "2" from the RTI photo directly revises Brandes' previous reading of the year character in line 6 of the Pucangan inscription which he reads as "939" as written in OJO LXII line 6 (See: Brandes, 1913, p. 137). Unfortunately, the author did not succeed in obtaining the absklat as a reference for Brandes' reading, so we are not able to compare between the two. However, at least the RTI processing image of the Pucangan inscription fragment shows and confirms that the RTI technique can be used to facilitate reading inscription characters or even further can be used to double-check the reading of dubious characters.

Other photogrammetric techniques that can be used for documenting and reconstructing carvings on stone inscriptions are with the Geographic Information System (GIS) approach. The process begins with the process of taking an image as is done in other photogrammetric methods, then forming it into a Mesh and adding a Digital Elevation Model (DEM) to the existing Mesh model. This GIS approach provides an overview of the surface of the earth that is curvy, when scaled downward to resemble the stone surface of the inscription, we will also be able to see the shadow of the valley bounded by the slopes and peaks. Likewise, the mesh model has DEM numbers. With the help of the application it will be possible to do a side slice of the model. The results of the side slices from the stone model will get the shape of valleys, mountains and peaks. Data in the form of the 
depth and the width of the existing carvings are used as a benchmark for digitally reconstructing other dubious carvings. The results obtained are used to better read the worn inscriptions.

The author has conducted experiments using photogrammetric techniques on a short inscription at the Liyangan site, Temanggung, which was found worn and hard to read. The results that have been carried out to date, although not yet at a satisfactory stage, can be proven that the photogrammetric techniques can clarify the worn-out carvings on the inscription stone and reconstruct the shape of the characters. Examples of the process and results of the experiments carried out can be seen in Figures 10, 11 and 12.

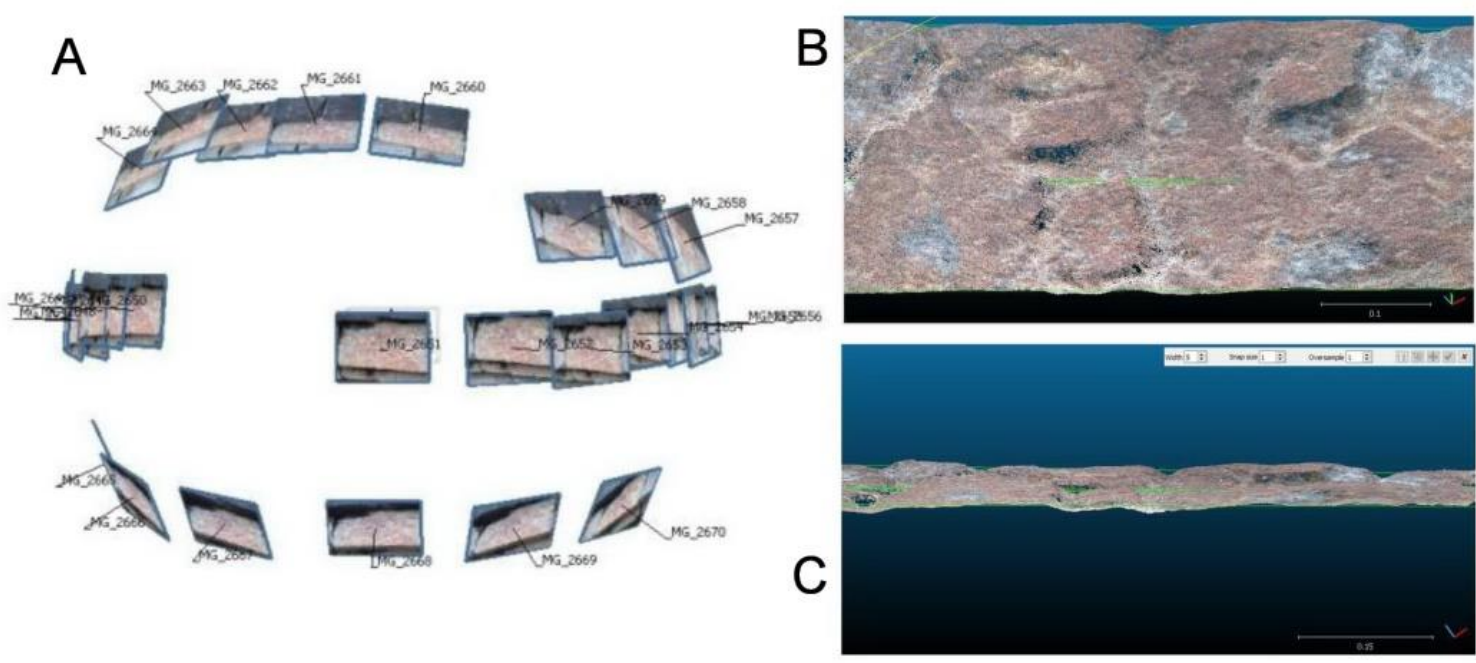

Figure 10. One of the Uses of Photogrammetry for Documenting and Reconstruction Experiments on the Carving of Short Inscription Found at the Liyangan Site in Temanggung, Central Java

(Source: Goenawan A. Sambodo documentation)

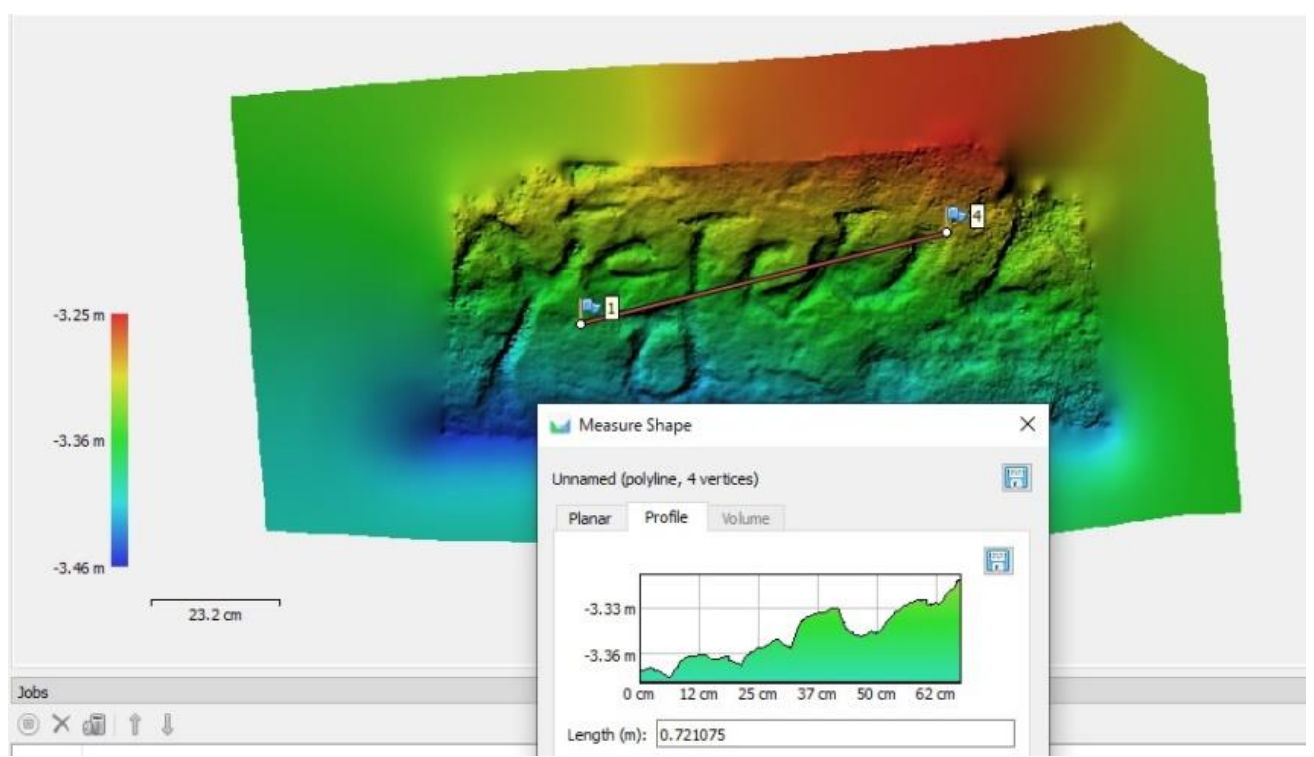

Figure 11. Reconstruction Steps by Observing Side Slices

of a DEM Processed Photo

(Source: Goenawan A. Sambodo) 


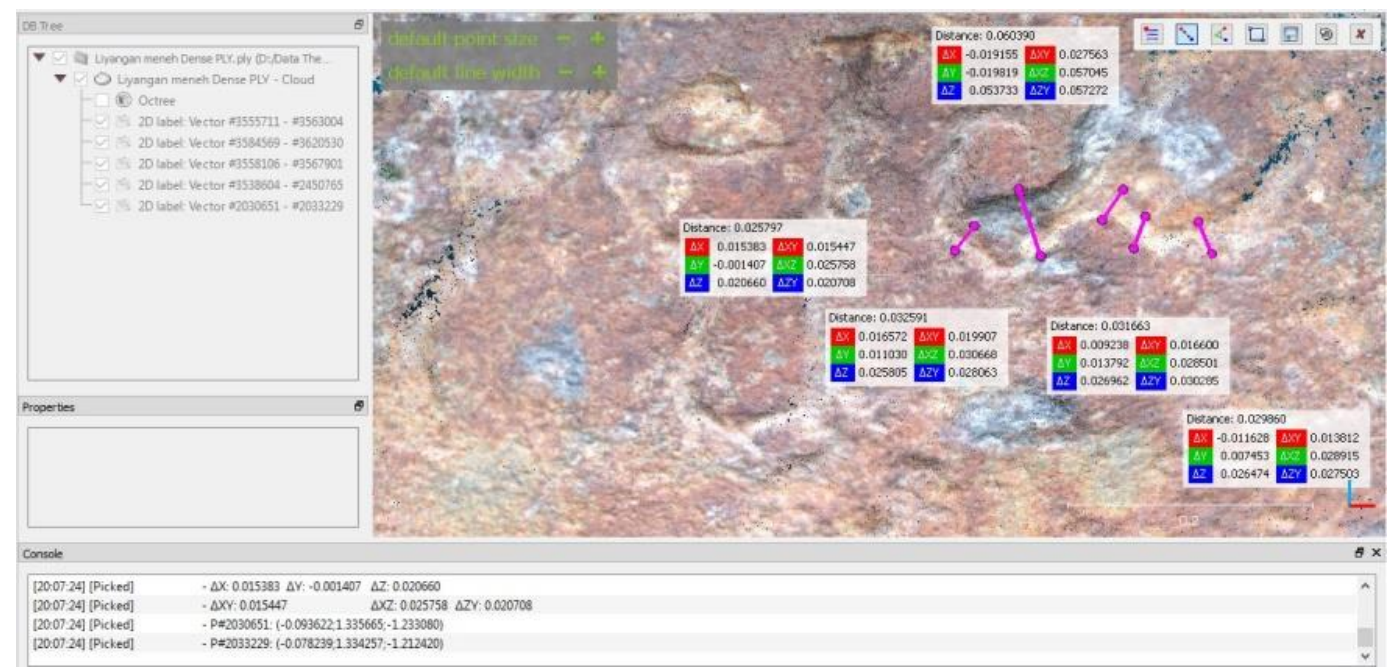

Figure 12. Reconstruction Steps by Looking at the Side of a Processed Photo with a DEM

(Source: Goenawan A. Sambodo)

The final result of processing the Liyangan short inscription image using photogrammetric techniques and DEM modeling shows convincing results that this technique can be used to reconstruct inscription characters that were previously difficult to read. Figures $13 \mathrm{~A}$ and B show comparisons of processed images with live photographs of short inscriptions on the Liyangan Site. The final image that has been processed (Figure 13A) shows a higher level of literacy than the direct photo of the inscription (Figure $13 \mathrm{~B}$ ). For the time being the result of the reading is "Kalumwayan", whose meaning will not be discussed further in this article because this article only focuses on the potential use of photogrammetric techniques in reconstructing worn and illegible inscriptions. Digital processing experiments with photogrammetric techniques like the one above is currently being developed by the author to obtain satisfactory reconstruction results so that the inscription characters can be read clearly and quickly.
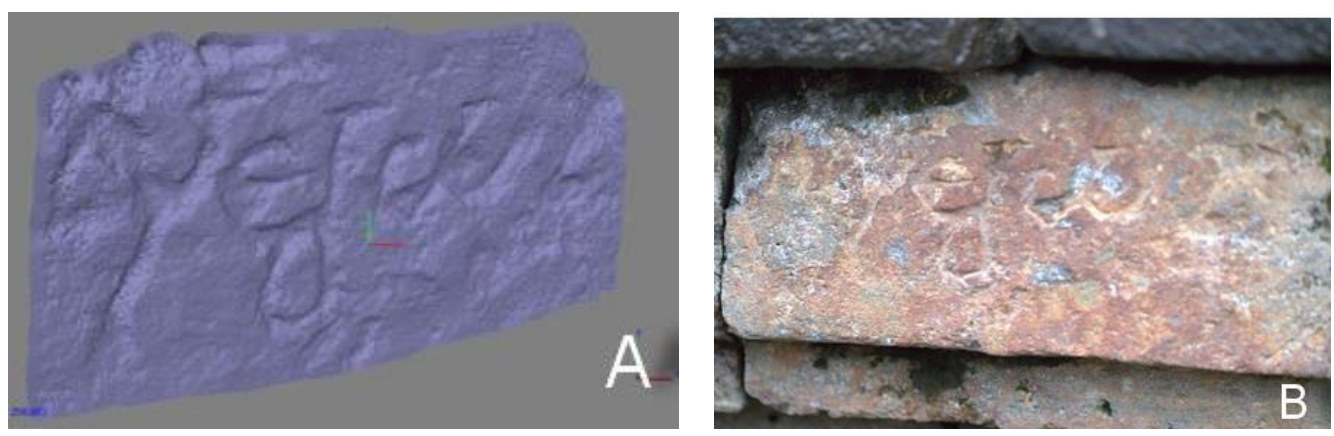

Figure 13. Photogrammetry Image Processing for Liyangan Inscription

A. Provisional results of reconstruction experiments

B. Initial photo before digitally reconstructed by photogrammetric technique

(Source: Goenawan A. Sambodo) 


\section{CONCLUSION}

This paper provides some information about photogrammetric techniques that can be used in the field of archaeological studies which are currently not widely used, especially in the field of epigraphy studies. This archaeological information presentation makes use of photographic spatial data in the form of three-dimensional models. This model is generated from the orbital shooting technique. The three-dimensional model produced is detailed so that the stone structure and especially the carvings in the stone are obtained with good detail and quality. The experiments conducted by the author in reconstructing the carved form of characters through this three-dimensional model show encouraging results and show great potential for future use.

In a way that is relatively easy to do, it is hoped that data collection and documentation of inscriptions that are still in-situ with photogrammetric techniques will be better and more detailed. So even if the inscription is lost, the detailed documentation in this way will be able to save data well. Data collection of the in-situ inscriptions in this way is more advisable because in most cases incriptions artifacts are often beyond good supervision, their existence becomes very vulnerable to looting for example. Data collection along with image processing through photogrammetric techniques on inscriptions that are already under good supervision - for example already in a museum or in an easily accessible location - will be even more useful, especially in increasing the readability of inscriptions so that the reading becomes more complete. This digital data will also be useful in the future to be used by other researchers who will use the data through more updated techniques in the future.

The problem that still exists in using this method is the limited human resources. It must be admitted that there are still very few archaeologists or epigraphers who are using this method. The use of photogrammetry for the field of cultural heritage, especially inscriptions, still needs to be improved. The existence of open source software applications which is easily available today should be able to trigger epigraphers to use it for disclosing inscriptions that still cannot be read completely. 


\section{ACKNOWLEDGEMENTS}

For all community friends who share joy and sorrow in exploring cultural heritage objects in the form of inscriptions both in Central Java, DIY and East Java with the author and for all the photos of the inscriptions, some of which are used to complement this paper, we are sending our gratitude. In particular, I would like to thank Mr. Arlo Griffiths for allowing the Pucangan inscription photo to be used as an experiment for one of the photogrammetric techniques, especially RTI, to complete this paper. This paper would not have been possible without the help of the above parties. 


\section{BIBLIOGRAPHY}

Boechari. (1977). Epigrafi dan Sejarah Indonesia. Majalah Arkeologi, I (2), pp. 1-40. FSUI, Jakarta.

Brandes, J.L.A. (1913). “Oud-Javaansche Oorkonde, nagelaten transcripties van wijlen Dr. J.L.A. Brandes, uitgegeven door N.J. Krom” . Verhandelingen van het Koninklijk Instituut voor Taal-, Land-en Volkenkunde deel 60

Caine, Moshe \& Maggen, Michael. (2017). Low Cost Heritage Imaging Techniques Compared. DOI: http://dx.doi.org/10.14236/ewic/EVA2017.85

Casparis, J.G. de. (1975). Indonesian Palaeography (A History of Writing in Indonesia from the Beginning to C.A.D. 1500). Leiden/Koln.

Cultural Heritage Imaging | Reflectance Transformation Imaging (RTI). (n.d.). Retrieved 4 June 2020, from http://culturalheritageimaging.org/Technologies/RTI/

Gajski, D., Solter, A., \& Gašparovic, M. (2016). Applications of macro photogrammetry in archaeology. International Archives of the Photogrammetry, Remote Sensing and Spatial Information Sciences - ISPRS Archives. https://doi.org/10.5194/isprsarchives-XLI-B5-263-2016

Grün, A., Remondino, F., \& Zhang, L. I. (2004). Photogrammetric reconstruction of the great buddha of Bamiyan, Afghanistan. In Photogrammetric Record. https://doi.org/10.1111/j.0031-868X.2004.00278.x

Jasiewicz, J., \& Stepinski, T. F. (2013). Geomorphons-a pattern recognition approach to classification and mapping of landforms. Geomorphology. https://doi.org/10.1016/j.geomorph.2012.11.005

Klinkenberg, Victor. (2014). Are we there yet? 3D GIS in archaeological research, the case of Tell Sabi Abyad, Syria, The Three Dimensions of Archaeology Proceedings of the XVII UISPP World Congress Volume 7/Sessions A4b and A12, pp. 39-47. Burgos, Spain

Mathys, Aurore \& Brecko, Jonathan \& Semal, Patrick. (2013). Comparing 3D digitizing technologies: What are the differences?.

DOI :10.1109/DigitalHeritage.2013.6743733.

Miles, James. (2015). Photogrammetry and RTI Survey of Hoa Hakananai'a Easter Island Statue. Papers from the 41st Conference on Computer Applications and Quantitative Methods in Archaeology Perth, 25-28 March 2013. Computer 
Applications and Quantitative Methods in Archaeology (CAA) / Amsterdam University Press, Amsterdam 2015, pp. 144-155.

Monna, F., Esin, Y., Magail, J., Granjon, L., Navarro, N., Wilczek, J., Saligny, L., Couette, S., Dumontet, A., \& Chateau, C. (2018). Documenting carved stones by 3D modelling - Example of Mongolian deer stones. Journal of Cultural Heritage. https:/ / doi.org/10.1016/j.culher.2018.04.021

Murtiyoso, Arnadi D. , dan Suwardhi, Deni. (2017). Teknik Pencocokan Citra dalam Fotogrametri untuk Dokumentasi Cagar Budaya dalam Bunga Rampai Forum Peneliti Muda Indonesia 2017, pp. 242-260. Penerbit ITB, Bandung

Nicolae, C., Nocerino, E., Menna, F., \& Remondino, F. (2014). Photogrammetry applied to problematic artefacts. International Archives of the Photogrammetry, Remote Sensing and Spatial Information Sciences - ISPRS Archives. https://doi.org/10.5194/isprsarchives-XL-5-451-2014

Papadaki, A. I., Agrafiotis, P., Georgopoulos, A., \& Prignitz, S. (2015). Accurate 3D scanning of damaged ancient greek inscriptions for revealing weathered letters. International Archives of the Photogrammetry, Remote Sensing and Spatial Information Sciences - ISPRS Archives.

https://doi.org/10.5194/isprsarchives-XL-5-W4-237-2015

Sapirstein, P. (2019). Segmentation, reconstruction, and visualization of ancient inscriptions in 2.5D. Journal on Computing and Cultural Heritage. https://doi.org/10.1145/3286977

Yokoyama, R., Shirasawa, M., \& Pike, R. J. (2002). Visualizing topography by openness: A new application of image processing to digital elevation models. Photogrammetric Engineering and Remote Sensing. 